\title{
Opioid Guidelines
}

\section{e Pharmacology of Opioids in the Treatment of Chronic Pain Syndromes}

Ricardo Vallejo, MD, PhD'1, Robert L. Barkin, PharmD², and Victor C. Wang, $\mathrm{PhD}^{3}$

From: ${ }^{1}$ Millennium Pain Center, Bloomington, IL; Department of Biological Sciences, Illinois State University, Normal, IL; and Clinica del Dolor, Centro Medico Teknon, Barcelona, Spain; ${ }^{2}$ Rush University Medical College, Chicago, IL; Northshore University Health System, Dept of Anesthesiology; Pain Centers of Evanston \& Skokie Hospitals, IL; 3University of Illinois School of Medicine, UrbanaChampaign, IL.

Dr. Vallejo is a Pain Medicine Physician Millennium Pain Center, Bloomington, IL; Department of Biological Sciences, Illinois State University, Normal, IL; and Clinica de Dolor, Centro Medico Teknon, Barcelona Spain. Dr. Barkin is Faculty Professor, Rush University Medical College Anesthesiology, Family Medicine and Pharmacology,

Chicago, IL; Clinical Pharmacologist and

Northshore University Health System, Dept of Anesthesiology; Pain Centers of Evanston \& Skokie Hospitals, IL. Dr. Wang is with the

University of Illinois School of Medicine, Urbana-Champaign, IL.

Correspondence: Ricardo Vallejo, MD, PhD Millennium Pain Center 1015 South Mercer Avenue Bloomington, IL 61701

Email: vallejo@millenniumpaincenter.com

Sources of Financial Support: Supported in total by the Millennium Pain Center, Bloomington, IL USA

Manuscript received: $06 / 18 / 201$ Revised manuscript received: 05/12/2011 Accepted for publication: $11 / 01 / 2010$

Free full manuscript www.painphysicianjournal.com
The perpetual pursuit of pain elimination has been constant throughout human history and pervades human cultures. In some ways it is as old as medicine itself. Cultures throughout history have practiced the art of pain management through remedies such as oral ingestion of herbs or techniques believed to have special properties. In fact, even Hippocrates wrote about the practice of trepanation, the cutting of holes in the body to release pain. Current therapies for management of pain include the pervasive utilization of opioids, which have an extensive history, spanning centuries.

There is general agreement about the appropriateness of opioids for the treatment of acute and cancer pain, but the long-term use of these drugs for treatment of chronic non-malignant pain remains controversial. The pros and cons regarding these issues are beyond the scope of this review. Instead, the purpose of this review will be directed towards the pharmacology of commonly prescribed opioids in the treatment of various chronic pain syndromes.

Opium, derived from the Greek word for "juice," is extracted from the latex sap of the opium poppy (Papaverum somniferum). The juice of the poppy is the source of some 20 different alkaloids of opium. These alkaloids of opioids can be divided into 2 chemical classes: phenanthrenes (morphine, codeine, and thebaine) and benzylisoquinolines (agents that do not interact with opioid receptors).

Key words: Opioid metabolism, opioid interactions, morphine, codeine, hydrocodone, oxycodone, hydromorphone, methadone, intractable pain, endorphins, enkephalins, dynorphins, narcotics, pharmacology, propoxyphene, fentanyl, oxymorphone, tramadol

Pain Physician 2011; 14:-E343-E360 piates are drugs derived from opium, referring specifically to the naturally occurring alkaloids derived from the poppy whereas an opioid is regarded as any chemical, natural or synthetic, that binds to the opioid receptor and can be antagonized by naloxone. Opioid agonists, opioid antagonists, opioid peptides, and opioid receptors are included in the same category. Another commonly used nonscientific term - narcotics - describes opioidlike or, more specifically, morphine-like drugs and other drugs with potential for abuse.

The treatment of pain has recently been called 
a "crisis" as more physicians have become more hesitant to manage pain via opioids (1), likely due to either a lack of knowledge about opioid pharmacology, management of narcotic abuse, or the social stigma of narcotic medications. However, nowadays, it is possible to utilize opioid medications for effective pain management through science-based decision-making by tailoring to the patient's specific clinical profile. The clinician needs to be aware of the patient's medical history, including allergies, psychiatric history, renal and liver function, hypersensitivities, contraindications, side effects, genetic polymorphisms, and pharmacotherapy interactions $(2,3)$. For example, because many chronic pain patients are often on polymodal therapy, the prescriber must avoid or mitigate inhibition, induction, or competitive substrate inhibition of the cytochrome P450 system (CYP450) $(1,3,4)$. These interactions, coupled with unique patient characteristics, such as a genetic polymorphism (e.g. a deficit of cytochrome $2 \mathrm{D} 6$ or $\left.2 \mathrm{C}^{\prime} \mathrm{s}\right)$ or renal/hepatic insufficiency, can further complicate the clinical picture. The risks and benefits of opioids must also be taken into consideration with adequate knowledge of their use. This is especially true because of the potential for abuse, misuse, and diversion. As always with the use of opioids, the patient must be evaluated for abuse as well as adherence.

Two clinically important properties of opioids are physical dependence and tolerance. Physical dependence is the physiological response to abstinence or opioid reversal in a patient who has been receiving continuous opioids. Tolerance is the pharmacological phenomenon whereby chronic exposure to opioids results in the need to increase the dose of the drug to achieve constant nociceptive (analgesic) effect or a diminished nociceptive effect over time to a constant dosage (5). Clinically, this definition assumes no progression in the disease state (6).

Opioid mediated euphoria is modulated by the nucleus accumbens (NACc). Projections and integration from the ventral tegmental area (VTA) directed to the NAcc include the prefrontal cortex, amygdala, and from dopaminergic (DA) neurons within the VTA. These pathways ultimately innervate the mesolimbic/mesocortical pathways. Dopaminergic cell bodies in the VTA synthetize DA which modulate the NAcc to achieve the opioid induced euphoria. The 6-keto opioids (hydrocodone, hydromorphone, oxycodone) are prominent for euphorigenic effects and consequent abuse. The cell bodies of the mesolimbic/mesocortical DA system originate within the VTA. Therefore DA containing neurons in the VTA are subject to opioid excitation and consequent euphoria (7-9).

At the molecular level, opioid receptors are guanine protein coupled receptors and are widely distributed in the brain, spinal cord, and peripheral sensory and autonomic nerves. The relatively recent discovery of opioid receptors have impacted the majority of what we understand today about the effects and properties of opioids. The delta ( $\delta$ ) opioid receptor was first cloned in $1992(10,11)$, followed closely by the cloning of the mu $(\mu)$ and kappa ( $\kappa)$ receptors (12). A more recently discovered receptor, ORL1, has been included as another opioid receptor due to its high degree of structural homology $(13,14)$. While the opioid receptors are identified mainly in 3 major known subtypes (mu, kappa, and delta), several other clinically significant subtypes may exist. For example, though there is only one cloned mu opioid receptor, several forms of the mu receptor mRNA arise from alternative splicing. The resulting receptors differ at the end C-terminal tail, exhibiting differences in the binding profile of opioid ligands. The mu receptors are generally responsible for supra-spinal and spinal analgesia (15). The clinical significance of the 10 or more cloned mu opioid receptor subtypes is so far unclear. The distinction between mu- 1 and mu- 2 receptors is based mainly on the preferential blockade of the mu-1 receptor by the antagonist naloxone.

Similar to the mu receptor, only one delta gene receptor has been identified; however, delta- 1 and delta-2 receptors have been differentiated by agonist and antagonist ligands (16). Although several kappa subtype receptors have been proposed, at this point the kappa-2 and kappa-3 subtypes are poorly defined based on molecular and pharmacological studies (17) (Table 1).

The analgesic properties of opioids are due to simulating endogenous properties of pain perception. Endogenous opioids include endorphins, enkephalins, and dynorphins. By interacting with their natural ligands, opioid receptors located in the hypothalamus are involved in temperature regulation and hormonal secretion, while the receptors in the forebrain are involved with behavioral patterns including anxiety and expression of emotions (18). Opioids exhibit their analgesic effects by 1 ) inhibition of calcium influx in the presynaptic membrane (19-22), inhibiting neurotransmitter release (substance P) (22-24); 2) hyperpolarization of presynaptic cells by increased potassium outflow (25-27), preventing nociceptive afferent information from spreading to adjacent neurons (28); and 3) cen- 
Table 1. Properties of opioid receptors.

\begin{tabular}{|c|c|c|c|c|}
\hline Opioid receptor & Natural ligand & Selective agonist & Properties & Antagonist \\
\hline $\mathrm{Mu}$ & $\begin{array}{l}\text { Enkephalins } \\
ß \text { endorphins }\end{array}$ & $\begin{array}{l}\text { Morphine, sufentanyl } \\
\text { DAMGO }\end{array}$ & $\begin{array}{l}\text { Analgesia, euphoria, tolerance, depen- } \\
\text { dence, immune suppression, respiratory } \\
\text { depression, emesis }\end{array}$ & Naloxone Naltrexone \\
\hline Mu-1 & & & & Naloxonazine \\
\hline \multicolumn{5}{|l|}{$\mathrm{Mu}-2$} \\
\hline Kappa & $\begin{array}{l}\text { Dynorphin } \\
\text { ß endorphins }\end{array}$ & $\begin{array}{l}\text { Bremazocine } \\
\text { Trifluadom }\end{array}$ & $\begin{array}{l}\text { Analgesia, sedation, myosis, diuresis, } \\
\text { dysphoria }\end{array}$ & TENA, nor-B NI \\
\hline Delta & $\begin{array}{l}\text { Enkephalins } \\
\text { ß endorphins }\end{array}$ & $\begin{array}{l}\text { DADLE } \\
\text { DSLET }\end{array}$ & $\begin{array}{l}\text { Analgesia, immune stimulation, respira- } \\
\text { tory depression }\end{array}$ & Naltrindole \\
\hline
\end{tabular}

DAMGO = D-Ala2, N-MePhe4, Gly-ol-enkephalin; nor-BNI = norbinaltorphimine; DADLE = D-Ala(2),D-Leu(5)-enkephalin; DSLET = DSer2-Leu-Enkephalin-Thr6; TENA = naloxone, Mr 2266, WIN 44441.

tral modulation of nociceptive information at the limbic system (29-32). Opioids bind to specific receptors in the pre- and post-terminal nerve endings resulting in inhibition of a release of the excitatory neurotransmitter (19-32).

Once an opioid interacts with its receptor, the complex formed will determine the effect. This interaction is reversible, and increasing or decreasing the opioid occupancy may increase or decrease the effect. Therefore, the most important factor of the opioid effect will be the concentration of the opioid at the level of the receptor. For practical reasons, this measurement is not performed, and plasma concentrations of the drug may be used as an indirect value to calculate the concentration at the receptor site. Any factor that affects the plasma concentration will alter the concentration at the receptor site. Those factors include absorption, distribution, biotransformation metabolism, and excretion. Following absorption, the plasma opioid concentration is determined by distribution to the site of action, storage in inactive sites, and tissue and organ elimination. Biotransformation for most opioids occurs hepatically, producing inactive or less active compounds than the parent drug (Table 2).

For an opioid to reach its target, it should cross different biological membranes. The most important properties for an opioid to cross a membrane are its molecular weight, ionization, and lipid solubility. The size of almost all opioids is small and therefore this factor does not influence the availability of the opioid at the receptor site. Non-ionized molecules cross membranes more readily and those opioids with the lower $\mathrm{pK}_{\mathrm{a}}$ will reach higher concentrations in the tissues. Finally, the more lipid soluble the opioid is, the more rapidly it will cross the membrane.

\section{Agonist And Antagonist Opioids}

When referring to the response of a receptor when binding to a drug, it is important to explain that efficacy is defined as the maximal response obtained by an active agent and that potency refers to the dose-response relationship and is determined by pharmacokinetic factors and the affinity for the receptor. Due to differences in their tri-dimensional configuration, opioids vary in their affinity at the receptor binding site. This disparity in affinity at the receptor binding site is one of the explanations for the wide variation in opioid potency. Another factor contributing to opioid potency is the differences in intrinsic activity (the degree of conformational change in the receptor site) and the resultant biological response. In other words, binding properties and activity at the receptor level are reflected in the differences in opioid potency (33).

On the other hand, the intensity and affinity of the binding with the receptor determines the duration of action (34). For example, sufentanil, with its high affinity for the receptor has a high potency, whereas buprenorphine, with its slow dissociation from the receptor, has a long duration of action and consequently lower potency.

\section{Classification of Opioids}

Opioids can be classified according to their interaction with the opioid receptors (Table 3$)(23,33,34)$.

1. Agonists bind the receptor stimulating physiological activity and have no ceiling in their analgesic effects.

2. Antagonists do not have intrinsic pharmacological 
Table 2. Opioid CYP metabolism.

\begin{tabular}{|c|c|c|c|c|}
\hline Opioid & PG Risk Factor & CYP Substrate & CYP Inducer & CYP Inhibitor \\
\hline Alfentanil & $\mathrm{C}$ & $3 \mathrm{~A} 4$ & & \\
\hline Buprenorphine & $\mathrm{C}$ & $3 \mathrm{~A} 4$ & & 2D6, 3A4 \\
\hline Butorphanol & $\mathrm{C} / \mathrm{D}$ & & & 2D6 \\
\hline Codeine & $\mathrm{C} / \mathrm{D}$ & 2D6, $3 \mathrm{~A} 4$ & & 2D6 \\
\hline Dihydrocodeine & $\mathrm{B} / \mathrm{D}$ & 2D6 & & \\
\hline Fentanyl & $\mathrm{C} / \mathrm{D}$ & $3 \mathrm{~A} 4$ & & $3 \mathrm{~A} 4$ \\
\hline Hydrocodone & $\mathrm{C} / \mathrm{D}$ & 2D6 & & \\
\hline Hydromorphone & $\mathrm{C} / \mathrm{D}$ & $\begin{array}{l}\text { Phase II glucuronidation conjugated 6-OH minor } \\
\text { metabolites }(6 \mathrm{HG}<3 \mathrm{HG})\end{array}$ & & \\
\hline Levorphanol & $\mathrm{B} / \mathrm{D}$ & Hepatic & & \\
\hline Meperidine & $\mathrm{C} / \mathrm{D}$ & $2 \mathrm{D} 6,2 \mathrm{C} 19,3 \mathrm{~A} 4$ & & \\
\hline Methadone & $\mathrm{C} / \mathrm{D}$ & $2 \mathrm{C} 9,2 \mathrm{C} 19,2 \mathrm{D} 6$ & & 2D6, 3A4 \\
\hline Morphine & $\mathrm{C} / \mathrm{D}$ & Phase II, 2D6 (minor) & & \\
\hline Nalbuphine & $\mathrm{B} / \mathrm{D}$ & Hepatic & & \\
\hline Oxycodone & $\mathrm{B} / \mathrm{D}$ & 2D6 & & \\
\hline Oxymorphone & $\mathrm{C}$ & Phase II glucuronidation & & \\
\hline Pentazocine & $\mathrm{C} / \mathrm{D}$ & Oxidation, glucuronidation & & \\
\hline Propoxyphene & $\mathrm{C} / \mathrm{D}$ & 2D6 & 2D6 & \\
\hline Remifentanyl & $\mathrm{C}$ & $\begin{array}{l}\text { Unknown CYP450 nonspecific esterases (blood) } \\
\text { and tissue }\end{array}$ & & 2D6 \\
\hline Sufentanil & $\mathrm{C}$ & $3 \mathrm{~A} 4$ & & \\
\hline Tramadol & $\mathrm{C}$ & 2B6, 2D6, 3A4 & & \\
\hline Tapentadol & $\mathrm{C}$ & $85 \%$ Phase II; 15\% CYP450 (13\% 2C9, 2C19, 2\% 2D6) & & \\
\hline
\end{tabular}

activity but can interfere with the actions of an agonist agent if both interact with the same receptor. Antagonist agents can be competitive if they bind to the same receptor, and non-competitive if they block the effects in a different way.

3. Agonist-antagonist drugs have a ceiling effect for antinociception and have agonist effects on some receptors and opposite effects in different types of receptors. Thus, co-administration of an opioid agonist with an opioid antagonist, an agonist/antagonist, or a partial agonist, may result in the development of withdrawal symptoms.

4. Partial agonists, also having a ceiling effect for antinociception, have low efficacy for the opioid receptor.

\section{Relative Potency and Equianalgesic Doses}

Relative potency is defined as the ratio of 2 analgesics required to achieve the same analgesic effect
$(35,36)$. The standard comparative dose of morphine used to determine relative potency of other opioids is $10 \mathrm{mg}$ morphine administered intravenously (IV). Commonly used equianalgesic tables provide merely a rough estimate of conversion for initial doses between different opioids (Table 4). In comparing these tables it is evident there are significant differences. Further such tables are unidirectional. Nevertheless, when considering such tables, it is important to realize that many variables can influence the correct equianalgesic dose. The variables worth mentioning include the intensity and type of pain, duration of exposure to the chosen opioid, age, route of administration, level of consciousness, metabolic disorders, and presence of active opioid metabolites. Furthermore, many of such tables reflect a variety of patients/subjects tested - oncology, chronic, postoperative, animal models, and acute one-dose studies to name few. 
Table 3. Classification of opioids.

\begin{tabular}{||c|c|c|c|}
\hline Agonists & Antagonists & Agonist/antagonists & Partial agonists \\
\hline Morphine Codeine & Naloxone & Nalorphine & Meptazinol \\
Oxycodone & Naltrexone & Pentazocine & Nalbuphine \\
Pethidine & Nalmefene & Butorphanol \\
Diamorphine & Diprenorphine & Dezocine & \\
Hydromorphone & & & \\
Levorphanol & & & \\
Methadone & & & \\
Fentanyl & & & \\
Sufentanyl & & & \\
Remifentanyl & & & \\
Tramadol & & & \\
Tapedolol & & & \\
\hline
\end{tabular}

Table 4. Approximate conversion chart for "equianalgesic" initial doses of opioids.

\begin{tabular}{|c|c|c|}
\hline Drug & Route & Equianalgesic Dose \\
\hline Morphine & $\begin{array}{l}\text { Parenteral } \\
\text { PO }\end{array}$ & $\begin{array}{c}10 \mathrm{mg} \\
30 \mathrm{mg} \text { (chronic) } \\
60 \mathrm{mg} \text { (acute) }\end{array}$ \\
\hline Codeine & $\mathrm{PO}$ & $200 \mathrm{mg}$ \\
\hline Fentanyl & Transdermal & 12.6 to $25 \mathrm{mcg} / \mathrm{hr}$ \\
\hline Hydrocodone & $\mathrm{PO}$ & $20-30 \mathrm{mg}$ \\
\hline Hydromorphone & $\begin{array}{l}\text { Parenteral } \\
\text { PO }\end{array}$ & $\begin{array}{c}1.3 \text { to } 1.5 \mathrm{mg} \\
7.5 \mathrm{mg}\end{array}$ \\
\hline Meperidine & $\begin{array}{l}\text { Parenteral } \\
\text { PO }\end{array}$ & $\begin{array}{c}75 \mathrm{mg} \\
300 \mathrm{mg}\end{array}$ \\
\hline Methadone & $\begin{array}{c}\text { Parenteral } \\
\text { PO }\end{array}$ & Variable drug titration \\
\hline Oxycodone & $\mathrm{PO}$ & $20-30 \mathrm{mg}$ \\
\hline Oxymorphone & $\begin{array}{c}\text { PO } \\
\text { Parenteral }\end{array}$ & $\begin{array}{c}10 \mathrm{mg} \\
1 \mathrm{mg}\end{array}$ \\
\hline Tramadol & $\mathrm{PO}$ & undetermined \\
\hline Buprenorphine & Parenteral & $0.3 \mathrm{mg}$ \\
\hline Tapentadol & $\mathrm{PO}$ & $100-150 \mathrm{mg}$ \\
\hline
\end{tabular}

Note: In making conversions, patients may amalgamate euphoria and analgesia, consequently analgesia may be misrepresented by euphoria and its expectation for pain relief.

Dose Conversion Guideline:

- If switching to methadone, reduce the dose by $75 \%$ to $90 \%$ and titrate slowly.

- If switching to transdermal fentanyl it may be necessary to reduce the equianalgesic dose.

- Consider further changes in the adjusted equianalgesic dose based on pain source of medical conditions, patient activity, patient functionality and pain complaints, patient's pharmacokinetic profile, comorbidities, and pharmacotherapy. 


\section{Opioid Agonists}

\section{Morphine}

Morphine is a phenanthrene opioid receptor agonist that binds strongly to the mu opioid receptor, but also has agonistic effects at the kappa and delta receptors. Morphine is the prototype opioid agonist which increases the threshold of pain perception. It is commonly accepted that the effect of morphine is more pronounced in nociceptive response arising from viscera, joints, and skeletal structures than in neuropathic pain $(37,38)$. Other common effects of morphine include sedation, nausea, a feeling of body warmth, pruritus, urinary retention, euphoria, and decreased ability to concentrate. Constipation remains as the only side effect lacking tolerance (39-45).

Morphine can be administered intramuscularly (IM), intravenously (IV), subcutaneously (SC), rectally, epidurally, intrathecally (IT), or orally (PO). Absorption after IM/SC injection has an onset of effect in about 15 to 30 minutes, with peak affect in 45 to 90 minutes. The duration of action is 4 hours. After IV injection, peak effect is observed in 15 to 30 minutes. Only a small portion of IV- administered morphine reaches the central nervous system (CNS). Reasons for poor penetration into the CNS are partially a result of its relatively poor lipid solubility, high degree of ionization at physiologic $\mathrm{pH}$, protein binding, and rapid metabolism. CNS concentrations of morphine reach peak levels later than plasma peak concentrations and decay more slowly, resulting in a paradoxical response where the analgesic and respiratory depressant effects may not correlate with plasma concentrations. Morphine is exposed to an extensive first-pass hepatic metabolism (degradation by the liver), so only $40 \%-50 \%$ of the orally administered dose reaches the CNS $(46,47)$.

Orally administered morphine is available in extended-release and short-acting formulations (48). The $\mathrm{t}_{1 / 2} \beta$ is 2 to 4 hours for immediate release oral forms. Recently, the addition of naltrexone to the extendedrelease oral morphine has become available in an effort to prevent tampering and possible diversion (49).

Metabolism: Morphine undergoes hepatic and extra-hepatic (renal) conjugation with glucuronic acid by the UDP-glucuronosyl transferase-2B7 and minor CYP2D6. About $75 \%$ of morphine is metabolized to morphine-3-glucuronide (M3G) and 5\%-10\% to morphine-6-glucuronide (M6G). M3G does not bind to opioid receptors and thus lacks any analgesic effect, but may be associated with neurotoxicity; whereas, the
M6G does bind to the mu receptor and is more potent than the parent morphine. It is estimated that $5 \%$ of morphine is demethylated to normorphine and a small amount of codeine and hydromorphone may also be formed. Elimination is mainly renal, with only $7 \%-10 \%$ undergoing biliary excretion $(46,47,50)$. Pregnancy (PG) category is $\mathrm{C}$.

\section{Hydromorphone}

Hydromorphone hydrochloride (dihydromorphinone and dimorphone), a hydrogenated ketone (6-keto opioid) of morphine, is a pure opioid agonist. The effects are similar to morphine (51). Currently, an extended-release hydromorphone formulation is available as well (52).

Hydromorphone is rapidly absorbed from the gastrointestinal (GI) tract and is largely metabolized in first pass phase II metabolism by glucuronidation. Exposure of hydromorphone is dose-proportional between the range of 2 and $8 \mathrm{mg}$. In vivo bioavailability following single-dose administration of the $8 \mathrm{mg}$ tablet is approximately $24 \%$ (coefficient of variation $21 \%$ ). The peak plasma hydromorphone concentrations are attained within 30 minutes to one hour (53-56). Plasma protein binding is $8 \%$ to $19 \%$.

Common to other opioid analgesics, hydromorphone suppresses the cough reflex by a direct action at the cough center in the medulla (57). Hydromorphone may also cause dose-related respiratory depression, mood changes, mental clouding, euphoria, dysphoria, nausea, vomiting, and electroencephalographic (EEG) changes. Like other opioids, continued hydromorphone administration can result in constipation by decreasing gastric, biliary, and pancreatic secretions as well as Gl motility, although constipation is not as severe as with morphine. Hydromorphone may cause hypotension due to histamine release from mast cell degranulation or peripheral vasodilation. Hydromorphone has a doserelated direct effect on brain stem respiratory centers as with other opioids. The respiratory depression also involves a reduction in the responsiveness of the brain stem respiratory centers to hypercarbia.

Metabolism: Hydromorphone undergoes extensive hepatic metabolism in the liver via glucuronidation, largely to hydromorphone 6-glucuronide (H-6-G) by phase II metabolism, which appears to lack analgesic effects. Accumulation of H-6-G, as in renal insufficiency, leads to the development of myoclonus, agitation, and seizures similar to M3G events $(58,59)$. Interestingly, the neuroexcitatory effects of hydromorphone-3-glucuro- 
nide ( $\mathrm{H}-3-\mathrm{G})$ are more intense than those seen in the metabolite of morphine (M-3-G) (60). This molecule is subject to abuse, misuse, and diversion. PG category is C.

\section{Codeine}

Codeine was initially isolated in 1932 by PierreJean Robiquet (61) and has become the most widely used opioid in the world. Codeine (3-methylmorphine), a natural isomer of methylated morphine, is an opiate used for its analgesic, antitussive, and antidiarrheal properties. It is the prototype of the weak to mid-range opioid. Codeine is actually a prodrug (inactive in its native form) that is metabolized in the liver by cytochrome P450 enzyme CYP2D6 and CYP3A4 with some 2D6 inhibition, resulting in the active compound morphine and codeine 6 -glucuronide $(50,62,63)$. About $5 \%-10 \%$ of codeine will be converted to morphine, with the remainder either free, conjugated to form C-6-G, or converted to norcodeine and hydromorphone to a lesser extent. Because codeine depends on the CYP2D6 metabolism for conversion into the active metabolites, it is important to consider genetic polymorphisms where a certain percentage of the population are poor metabolizers due to deficiencies of CYP2D6 (approximately $6 \%-10 \%$ of Caucasians, $2 \%$ of Asians, and $1 \%$ of Middle-Easterners (64). Medications like selective serotonin reuptake inhibitors, diphenhydramine, and bupropion inhibit CYP2D6 which may explain the lack of pain relief in certain patients. Codeine is metabolized in the liver to the primary active compounds morphine and codeine-6-glucuronide (C6G) $(50,65,66)$. Onset of analgesia for the oral form is $\leq$ one hour and IM/SC $\leq 30$ minutes. The duration of action is 4 to 6 hours and protein binding is $\leq 1 \%$. $T_{1 / 2} \beta$ is 2.5 to 3.5 hours.

Codeine is less potent than morphine, an oral dose of $200 \mathrm{mg}$ is approximately equivalent to $30 \mathrm{mg}$ of oral morphine, and has a correspondingly lower dependence-liability than morphine (65). However, just as the case with other opioids, continued use can result in physical dependence. Fortunately, the withdrawal symptoms of codeine are relatively mild. A maximum of $60 \mathrm{mg} /$ dose is suggested. PG category is C.

\section{Fentanyl}

Fentanyl (N-[1-\{2-phenylethyl\}-4-piperidinyl]-Nphenylpropanamide) is a potent synthetic narcotic analgesic with both rapid onset and short duration of action. Fentanyl is a strong agonist of the mu-opioid and the high lipophilicity allows it to readily penetrate the
CNS. Fentanyl is 100 times more potent than morphine. Analogs of fentanyl include sufentanyl, alfentanyl, remifentanyl, and lofentanyl, all differing in potency and/or duration of action $(67,68)$.

The high lipid solubility not only confers the ability of fentanyl to pass readily through the blood-brain barrier, but also to pass through other cellular barriers (69-71). This has led to the administration of fentanyl both by transdermal and buccal routes. The widespread use of fentanyl for palliative and chronic pain began with the transdermal patch and more recently with more rapid-acting formations such as transmucosal and buccal tablets. The transdermal dosage form releases fentanyl by diffusion/osmosis into body fat, which slowly releases the drug over 48 to 72 hours, allowing for long-lasting analgesia. The patch takes effect within 8-12 hours, thus fentanyl patches are often prescribed with another short-acting opioid (i.e., morphine, tapentadol, oxycodone) for breakthrough pain. A fentanyl lozenge is a solid formulation on a stick that dissolves slowly in the mouth (ideally over 15 minutes) for transmucosal absorption. These lozenges are intended for opioid-tolerant individuals and are effective in treating breakthrough pain in both cancer and non-cancer patients. Recently, other fentanyl preparations have become available, including buccal tablets or patches, nasal sprays, inhalers, and active transdermal patches (heat or electrical).

Metabolism: Fentanyl is metabolized primarily via the cytochrome P450 3A4 isoenzyme system, via oxidative $\mathrm{N}$-dealkylation to norfentanyl and other inactive metabolites and weakly inhibits CYP3A4. Within 72 hours of IV fentanyl administration, approximately $75 \%$ of the dose is excreted in urine, mostly as metabolites with less than $10 \%$ representing unchanged drug and approximately $9 \%$ excreted in the feces, primarily as metabolites. Fentanyl undergoes a pulmonary first pass metabolism. Mean values for unbound fractions of fentanyl in plasma are estimated to be between $13 \%$ and $21 \%$. When applied transdermally, virtually the entire delivered dose appears in the circulatory system unchanged $(72,73)$. Following transmucosal administration, fentanyl is readily absorbed with a bioavailability of between $45 \%$ and $65 \%$. Following the initial absorption from the mucosa, peak plasma concentrations are generally attained within one hour. Between $20 \%$ to $50 \%$ of the total administered dose is absorbed transmucosally and the remainder is swallowed and undergoes a more prolonged absorption in the Gl tract (6971). Because the drug is metabolized by the liver and 
excreted by the kidney, dosing considerations should be taken when administered to patients with impaired renal or hepatic function $(50,74,75)$.

\section{Levorphanol}

Levorphanol tartrate (levo-3-hydroxy-N-methylmorphinan) is a potent opioid synthetic analgesic similar to morphine in its actions. Each $\mathrm{mg}$ of levorphanol tartrate is equivalent to $0.58 \mathrm{mg}$ levorphanol base. Levorphanol tartrate is a white crystalline powder, soluble in water and ether, but insoluble in chloroform. The recommended oral starting dose is $2 \mathrm{mg}$. This may be repeated at 6 to 8 hour intervals as needed. Higher doses may be appropriate in opioid tolerant patients. Levorphanol is 4 to 8 times as potent as morphine and has a longer half-life (76). Levorphanol has strong affinity for mu, delta, and kappa opioid receptors, and its interaction with these receptors is stronger than morphine (77-81).

As with other mu-agonist opioids, levorphanol is believed to act at receptors in the periventricular and periaqueductal gray matter in both the brain and spinal cord to alter the transmission and perception of pain. Levorphanol also has some N-Methyl-D-aspartate (NMDA) inhibitory effects and may, in addition to its primary effect at the opioid receptor, inhibit reuptake of serotonin and noradrenaline. Its NMDA actions may be useful in treating neuropathic pain conditions where other analgesics may not be as effective $(76,82)$.

The onset of analgesia and the peak analgesic effect are similar to morphine at equianalgesic doses. Also similar to morphine is the degree of respiratory depression at equianalgesic doses $(39,52,83)$. Levorphanol produces a positive effect on mood in many individuals (84). The rate of development of tolerance is highly variable, and is determined by the dose, dosing interval, age, usage of concomitant drugs, and physical status.

Metabolism: The pharmacokinetics of levorphanol have been studied following IV and PO administration. Following IV administration, plasma concentrations of levorphanol decline tri-exponentially with a terminal half-life of 11 to 16 hours and a clearance of 0.78 to 1.1

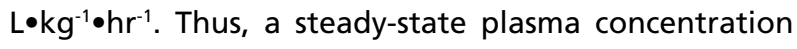
should be achieved by the third day of dosing. Levorphanol is rapidly distributed (< one hour) and redistributed (1-2 hours) following IV administration and has a steady-state volume of distribution of 10 to $13 \mathrm{~L} / \mathrm{kg}$. In vitro studies of protein binding indicate that levorphanol is only $40 \%$ bound to plasma proteins. Levorphanol is extensively metabolized in the liver by phase II metabolism and is eliminated as the glucuronide metabolite $(50,76)$.

Plasma concentrations of levorphanol following chronic administration increase with dose. However, the analgesic effect is dependent on the degree of tolerance. Expected steady-state plasma concentrations during 6-hour dosing can vary 2 to 5 times as compared to a single dose. This renally excreted inactive glucuronide metabolite accumulates with chronic dosing in plasma at concentrations that reach 5 -fold that of the parent compound.

The effects of age, gender, hepatic disease, and renal disease on the pharmacokinetics of levorphanol are not known. As with all drugs of this class, patients at the extremes of age are expected to be more susceptible to adverse effects because of a greater pharmacodynamic sensitivity and probable increased variability in pharmacokinetics due to age or comorbid disease. PG category is B/D (chronic use or high doses at term).

\section{Meperidine}

Meperidine, otherwise known as pethidine (Ethyl 1-methyl-4-phenylpiperidine-4-carboxylate) is a rapidacting synthetic opioid analgesic drug. It was first synthesized in 1932 as a potent anti-spasmodic drug, and is structurally similar to atropine. It remains about midway among the dozen opioids in potency. Meperidine acts primarily as a kappa opioid receptor agonist and, in addition to anticholinergic effects, has local anesthetic activity related to its interaction with sodium ion channels. Meperidine is indicated for the treatment of moderate to severe pain, and is available as a hydrochloride salt in tablets, as a syrup, or as IM or IV injection. Its use for chronic pain, however, is limited because of stimulating effects mediated by inhibition of the dopamine and norepinephrine transporter $(85,86)$, thereby increasing the risk for serotonin syndrome in patients using multiple selective serotonin reuptake inhibitors or monoamine oxidase inhibitors (87-89). These reactions could include coma, severe respiratory depression, cyanosis, hypotension, hyperexcitability, convulsions, tachycardia, hyperpyrexia, and hypertension $(90,91)$. A comprehensive discussion of meperidine is found elsewhere (92).

There appears to be some controversy concerning the primary method of action. Unlike morphine, meperidine has an affinity for kappa opioid receptor as well as the mu receptor $(93,94)$. Meperidine is more lipid-soluble than morphine, resulting in a faster onset of 
action. Oral bioavailability is $50 \%-60 \%$ in patients with normal hepatic function. Protein binding is $65 \%-75 \%$. A dose restriction of $600 \mathrm{mg}$ is noted with this agent due to accumulation.

Metabolism: Meperidine is metabolized in the liver via cytochrome P450, CYP2B6, CYP3A4, CYP2D6, CYP1A2, CYP2C19, and others. It undergoes hydrolysis to meperidinic acid followed by partial conjugation with glucuronic acid. Meperidine also undergoes $\mathrm{N}$-demethylation to normeperidine, which then undergoes hydrolysis and partial conjugation. Normeperidine, its major nonopioid metabolite, is about half as potent as meperidine. It has CNS excitatory effects as neurotoxic events that may lead to hyperexcitability and convulsions, especially in patients with renal impairment $(86,95)$. Normeperidine appears to be responsible for the unique and severe side effects - serotonin syndrome, seizures, delirium, dysphoria. Its duration of clinical effect is 120-150 minutes although it is typically administered in 4-6 hour intervals (87-91).

It appears that the nonopioid normeperidine is not reversible by naloxone. Utilization of the agent is declining and meperidine is falling into disuse. PG category is $C$.

\section{Methadone}

Methadone hydrochloride (6-[dimethylamino]-4,4diphenyl-3-hepatanone hydrochloride) is a synthetic opioid analgesic developed in Germany in 1937 with actions and uses similar to morphine. Its interaction with the mu opioid receptor produces morphine-like effects, including analgesia, euphoria, sedation, respiratory depression, miosis, bradycardia, and physical dependence. Methadone has also been found to interact with voltage-gated potassium channels in the myocardium, which may lead to QT prolongation (2,96-100). A high degree of caution is needed when co-prescribed with other QT prolonging therapies. Methadone is indicated for relief of severe pain, detoxification treatment of narcotic addiction, and temporary maintenance treatment of narcotic addiction. Unlike morphine, methadone is a racemic mix; one stereoisomer acts as a NMDA receptor antagonist, the other is a mu-agonist opioid. The potent NMDA-receptor antagonism plays an important role in the prevention of opioid tolerance, potentiation of opioid effects, and may make methadone more efficacious for neuropathic pain syndromes (101103). Methadone also blocks the $\alpha 3 \beta 4$ nicotinic acetylcholine receptor (104). The pharmacokinetics of methadone include a bioavailability after oral dosing of $80 \%$, and high tissue binding in the brain, liver, kidney, and muscle. Plasma protein binding is $85 \%$ to $90 \%$.

Metabolism: Methadone is metabolized in the liver by the enzymes CYP2B6, CYP2C19, CYP2D6, and others, although with great variability between individuals. CYP450 inhibition is at 2D6 and 3A4. Its main route of administration is oral with a half-life of 8 to 60 hours with a mean of around 22 hours. Since methadone has no active analgesic metabolites, no dose adjustment is needed in patients with compromised liver functions but avoid use in severe hepatic disease $(101,102)$. The analgesic duration of action is 3 to 6 hours after initial dosing and 8 to 12 hours after repeat dosing $(105,106)$.

Equianalgesic doses for methadone relative to other opioids are extremely variable and range from $0.1 \%$ to $10 \%$ morphine equivalents, based on dose. Since the equianalgesic doses are lower at higher doses, conversion to methadone in opioid-experienced patients should be done with a high degree of care and with minimal doses (107). In the United States, mortality associated with the use of methadone quadrupled in the period between 1996 and 2004 (108). The exact reason for this increase in mortality is unknown, as it has not been reported in patients treated in methadone clinics, pointing towards an indiscriminate increase in methadone prescription in patients with chronic pain.

Various factors make methadone a drug requiring careful monitoring for the treatment of chronic pain. Because of incomplete cross-tolerance, methadone is an alternative when patients are experiencing intolerable side effects to other opioids. A long duration of analgesia with chronic use allows for less frequent dosing than with other opioids (109). However, methadone is cautiously reserved for second-line treatment because of the difficulty in titrating patients and the delayed onset, and some patients may require a baseline EKG, repeated with dose increments (100). PG category is C.

\section{Hydrocodone}

Hydrocodone (dihydrocodeinone) is a semi-synthetic 6-keto opiate agonist and hydrogenated ketone derivative, structurally similar to codeine and producing effects most similar to morphine. According to IMS Health ${ }^{T M}$, a market intelligence agency for the pharmaceutical industry, hydrocodone is currently the most frequently prescribed opiate in the US with over 136 million prescriptions for hydrocodone-containing products dispensed in 2008. Because of escalating diversion and abuse of hydrocodone in recent years, the US Drug Enforcement Administration (DEA) is currently review- 
ing a petition to increase the regulatory controls on hydrocodone combination products from schedule III to schedule II of the Controlled Substances Act (CSA).

Hydrocodone is usually combined with a weaker analgesic such as acetaminophen, ibuprofen, or aspirin. Hydrocodone is taken orally and comes in tablet, capsule, syrup, and solution in immediate-release formulations and as an extended-release capsule or suspension. Specifically, hydrocodone acts primarily at the mu receptor, but also is a weak agonist at the delta and kappa receptors. Taken orally, hydrocodone is absorbed from the Gl tract and $20 \%$ to $50 \%$ is bound to plasma protein. Onset of analgesia is 20 to 30 minutes with duration of analgesia from 4 to 8 hours, and $t_{1 / 2} \beta$ is 3 to 4 hours.

Metabolism: The overall metabolism and routes of clearance of hydrocodone remain sketchy. Hydrocodone is known to be metabolized in the liver and in the intestinal mucosa. Hydrocodone undergoes cytochrome P450 oxidative metabolism to hydromorphone and norhydrocodone utilizing CYP2D6 and CYP3A4, which may contribute to its efficacy of analgesic action as well as the side effect profile (110-114). The cytochrome P450 isozyme CYP2D6 appears to be a significant contributor in the metabolism of hydrocodone. About $7 \%$ of Caucasians have inactivating or mutations in the gene encoding CYP2D6 or have complete deletion of the gene (113). In this type of patient the clearance of drugs metabolized by CYP2D6 can be 10-20 fold lower than in normal patients (115).

This molecule is the target of abuse, misuse, and diversion. PG category is $C$.

\section{Oxycodone}

Oxycodone

$([5 R, 9 R, 13 S, 14 S]-4,5 \alpha$-epoxy-14hydroxy-3-methoxy-17-methylmorphinan-6-one) is a potent synthetic opioid 6-keto opioid analgesic with agonist activity on the mu, delta and kappa receptors. Structurally similar to codeine and hydrocodone, oxycodone's equivalence with regard to morphine is 1:2. Oxycodone is formulated as both a single ingredient or compounded with other products such as paracetamol/ acetaminophen, ibuprofen, and aspirin. Oxycodone is available in immediate release tablets, solutions, and controlled-release tablets.

The pharmacological effects of oxycodone include euphoria, analgesia, sedation, relaxation, respiratory depression, constipation, papillary constriction, and cough suppression. Following oral administration, peak plasma levels of the drug are attained in approximately one hour (116). In contrast, after a dose of the oral continuous release (CR) formulation, peak plasma levels of oxycodone occur in about 2 to 3 hours. An initial bolus dose release of oxycodone (30\%-40\% of dose) is available in one to 2 hours of initial oral use of the controlled-release dosage form. Analgesic actions of immediate release oral immediate-release (IR) preparations of oxycodone start within 10-15 minutes and can last up to 5 hours versus one hour and 8-12 hours, respectively, with oral CR formulations (117-119). Oral bioavailability (CR) ranges from $60 \%$ to $87 \%$, and plasma protein binding is $45 \%$. The $t_{1 / 2} \beta$ for the IR formulation is about 2 to 3 hour, and about 5 hours for the CR form. As with most opiates, oxycodone misuse and abuse and prominent euphoria may lead to dependence and tolerance (120). In contrast to morphine, which interacts primarily with mu-opioid receptors, intrinsic antinociceptive effects of oxycodone are attenuated by administration of selective kappa-opioid receptor antagonists, norbinaltorphimine, suggesting that oxycodone acts as a kappa-opioid agonist with relatively low affinity for mu-opioid receptors $(121,122)$. This molecule is subject to known abuse, misuse, and diversion.

Metabolism: Oxycodone undergoes extensive metabolism by the cytochrome P450 2D6 enzyme system in the liver. Thus, doses must be reduced in patients with compromised liver function. While most of the drug is metabolized in the liver, the rest is excreted by the kidney along with the metabolites. The 2 main metabolites are oxymorphone, itself a potent analgesic, and noroxycodone, a weak analgesic. It is unclear whether, in fact, any of the metabolites actively contribute to the overall analgesic effects (117$119,123,124)$. PG is category B.

\section{Oxymorphone}

Oxymorphone (14-Hydroxydihydromorphinone) is among the newest additions to oral opioid pharmacotherapy. It is a semi-synthetic 6-keto opioid agonist. The duration of effect of the IR tablets is 5 to 8 hours. The duration of action and metabolic half-life (7-9 hrs) of IR oxymorphone tablets resemble analgesic preparations of methadone, levorphanol, piritramide, and extendedrelease forms of morphine, oxycodone, and ketobemidone. The extended-release oxymorphone tablets can provide detectable analgesia for 6 to as many as 36 hours (125). When compared with morphine, IV oxymorphone provides excellent analgesia with a lower incidence of sedation and higher patient satisfaction (126). 
Metabolism: Although oxymorphone is well absorbed from the gut, the liver eliminates most of the drug during the first pass; thus the oral bioavailability of oxymorphone is only $10 \%(2,127)$. The absorbed lipid-soluble oxymorphone easily and rapidly enters the CNS, binding mu-opioid receptors to produce analgesia. The volume of distribution of oxymorphone is $3 \mathrm{~L}$ $\mathrm{kg}$ (similar to morphine) with protein binding of about $10 \%$. Plasma concentrations reach $T_{\max }$ at 0.5 hours after single oral IR doses $(5,10$, or $20 \mathrm{mg}$ ) in healthy volunteers (128). Plasma oxymorphone concentrations taken during the multiple-dose period showed that $\mathrm{T}_{\max }$ remained at 0.5 hours and that steady-state was achieved after 3 days of oxymorphone IR dosing (128). As ingestion of food along with oxymorphone increases the $T_{\max }$ for the $C_{\max }$ by $38 \%-50 \%$, the drug should be taken on an empty stomach (129).

The extended-release oxymorphone is a newer formulation that uses a controlled-release technology to allow 12-hour dosing. Similar to the IR oxymorphone, single-dose pharmacokinetics demonstrate dose-proportionality and linearity over a wide dose range. The elimination half-life from single dosing of oxymorphone extended release is 9 to 11 hours. Plasma levels of oxymorphone are maintained over 12 hours with little fluctuation. Steady-state conditions were achieved in 3 days of 12-hour dosing. The $T_{\max }$ for the $C_{\max }$ occurr at 1.5 to 3.5 hours and are sustained for approximately 6 hours (130).

Oxymorphone is highly metabolized in the liver, principally by conjugation phase II metabolism with glucuronide, but with a lack of interaction with CYP450 system (131). Only $2 \%$ is excreted, unchanged, by the kidney (128). Oxymorphone's liver metabolism causes minimal potential drug-to-drug interaction with drugs metabolized by the CYP2C9 and CYP3A4 (132). In healthy volunteers, the elimination half-life of IR oxymorphone was approximately 8 hours, about double that of both morphine and oxycodone. As with many medications, plasma levels of oxymorphone were found to be higher (40\%) in elderly than in younger subjects. There is no known gender effect on the pharmacokinetics of oxymorphone. PG category is $C / D$ (prolonged administration or high dose at term). An extensive discussion of oxymorphone can be found elsewhere $(3,133)$.

\section{Tramadol}

Tramadol hydrochloride ([1R,2R]-rel-2[\{dimethylamino\}methyl]- 1-[3-methoxyphenyl] cyclo- hexanol) is a centrally acting synthetic analog of codeine with multiple actions. Pharmacologically similar to levorphanol, tramadol acts as an NMDA antagonist. Overall, tramadol is a weak mu opioid receptor agonist, reuptake blocker of serotonin, and inhibits neuronal norepinephrine reuptake. A recent evaluation of the efficacy of IV tramadol for postoperative analgesia found no difference when compared with acetaminophen (134). Tramadol is available in a wide array of formulations including capsules (immediate and extended release), tablets (for oral, extended release, sublingual or buccal routes), suppositories, tablets with acetaminophen, effervescent tablet and powders, solutions (both regular and preservative-free), and in powders for compounding.

Tramadol has traditionally been considered to have a lower risk of addiction and safety profile when compared to other opioids. Despite the safer profile, 2 significant serious adverse reactions include tramadol-seizure and serotonin syndrome. Although these complications may develop in patients using tramadol monotherapy, it appears more likely when large doses of tramadol are co-administered with other serotonin reuptake inhibitors and/or serotonergic agents (135).

Tramadol is well absorbed orally with an absolute bioavailability of $75 \%$. It has a volume of distribution of approximately $2.7 \mathrm{~L} / \mathrm{kg}$ and is only $20 \%$ bound to plasma proteins. Linear pharmacokinetics have been observed following multiple doses of 50 and $100 \mathrm{mg}$ to steady-state.

Metabolism: Tramadol is metabolized in the liver via the cytochrome P450 isozyme CYP2B6, CYP2D6, CY$\mathrm{P} 2 \mathrm{C} 19$, and CYP3A4, being $\mathrm{O}-$ and $\mathrm{N}$-demethylated into 5 metabolites. O-desmethyltramadol is the most significant CYP2D6 metabolite since it has 200 times more affinity for the mu receptor and has an elimination halflife of 9 hours -- 3 hours longer than that for parent compound tramadol itself. A slightly reduced analgesic effect will be seen in patients with slow CYP2D6 activity. Phase II hepatic metabolism renders the metabolites water-soluble, which are then excreted by the kidneys. Thus, reduced doses may need to be used in renal and hepatic impairment (136).

PG category is C. A comprehensive discussion of tramadol can be found elsewhere $(137,138)$.

\section{Tapentadol}

Tapentadol hydrochloride ([-]-[1R,2R]-3-[3-Dimethylamino-1-ethyl-2-methyl-propyl]-phenol hydrochlo- 
ride) is a centrally acting oral analgesic approved by the US Food and Drug Administration (FDA) in November of 2008. It is currently only available as IR. The binary mechanism of action of tapentadol appears to be 2 -fold. Similar to other opioid agonists, tapentadol binds to the mu opioid receptor (139). In addition, tapentadol also inhibits norepinephrine re-uptake. This latter characteristic makes tapentadol potentially more effective in treating neuropathic pain conditions $(2,140,141)$. The norepinephrine modulates the descending pathway by diminishing pronociceptive substance $P$ and also glutamate events on the ascending spinal pathway. The maximum dose is $600 \mathrm{mg} / 24$ hours.

Pharmacokinetic studies of tapentadol found that it follows a linear model. Oral absorption is rapid, reaching a $T_{\max }$ for the $C_{\max }$ in $\leq 1.5$ hours. Significant conjugation of tapentadol occurs $(85 \%$ with $15 \%$ by CYP450, specifically $13 \%$ by CYP2C9 and 2 C19, and $2 \%$ CYP2D6), and no active analgesic metabolites have yet been identified. More than $50 \%$ of the drug is excreted within 4 hours, primarily by the kidney. Plasma protein binding is about $20 \%$, and the $t_{1 / 2} \beta$ is 4 hours. Reported adverse effects appear to be dose-related and include sleepiness, dry mouth, nausea, and vertigo (139). No drug-drug interactions at CYP450 substrates have been identified. PG category is $C$. Both seizures and serotonin syndrome have been identified.

\section{Partial Agonists}

\section{Buprenorphine}

Buprenorphine $\quad(6,14-e t h e n o m o r p h i n a n-7-m e t h a-$ nol, 17-[cyclopropylmethyl]- $\alpha$-[1, 1-dimethylethyl]-4, 5-epoxy-18, 19-dihydro-3-hydroxy-6-methoxy- $\alpha$ methyl-, $[5 \alpha, 7 \alpha,\{S\}])$ is a thebaine derivative initially approved as an alternative to methadone for treatment of opioid addiction and recently approved by the US FDA for the treatment of moderate to severe chronic pain (142-144). The mechanisms of action are incompletely understood. Buprenorphine is a partial agonist at the mu opioid receptor that can also bind to kappa, as a weak antagonist, and delta opioid receptors (145). The affinity of buprenorphine for the delta receptor is 10 times lower than that for mu and kappa receptors. Recently, low doses of buprenorphine have shown to block the epsilon receptor (146).

Metabolism: Oral bioavailability of buprenorphine is low because of extensive first-pass hepatic metabolism $(147,148)$. However, the administration of buprenorphine by the sublingual (SL) or transdermal routes allows for bypassing of the first-pass hepatic metabolism. Buprenorphine is an extremely lipophilic compound that has a high affinity and dissociates very slowly from the mu-opioid receptor, resulting in a relatively long duration of analgesic action (149). The elimination half-life of buprenorphine in humans is either biphasic or triphasic $(150,151)$. Buprenorphine is highly bound $(96 \%)$ to plasma proteins, primarily to $\alpha$ - and $\beta$-globulin fractions (152). Buprenorphine is demethylated in the liver to form an active metabolite norbuprenorphine, and is also metabolized to other compounds by CYP3A4 and inhibits CYP1A2, 2A6, 2C19, 2D6, and by UGT1A3 and $2 B 7(153,154)$. The absorption of buprenorphine liquid from the SL mucosa is rapid, occurring within 5 minutes (155). The bioavailability of buprenorphine is approximately $30 \%$ by SL route, $70 \%$ by the IM route, and $15 \%$ by transdermal $(155,156)$. The mean terminal half-lives are 28 to 37 hours following SL administration, 2 to 3 hours following IV, and 19 hours following buccal administration. Average clearances following SL and buccal administrations are 210 and $712 \mathrm{~L}$ $\mathrm{hr}$, respectively (149). Peak plasma concentrations of SL buprenorphine were observed at 60 minutes following doses of 2 and $4 \mathrm{mg}$, and at 30 minutes for doses of 8 , 16 , and $32 \mathrm{mg}$. Plasma concentrations after administration of the $32 \mathrm{mg}$ dose were significantly elevated for up to 60 hours following medication administration. Following the SL buprenorphine 0.4 or $0.8 \mathrm{mg}$ doses, there was no significant rise in plasma concentrations for 20 minutes; the time to maximum concentration ranged from 90 to 360 minutes $(157,158)$. The average systemic bioavailability was $55 \%$, but variable.

Buprenorphine meets the requirements for a medication for transdermal administration. It has an octanol-to-water partition coefficient of 1217 (i.e., high lipophilicity), a molecular weight of 468 , and is 25 to 50 times more potent as an analgesic than morphine. Transdermal formulation allows a therapeutic blood level to be maintained over an extended period. In Europe and the US, a transdermal buprenorphine product has been approved and marketed and is available as multidose patches. Plasma levels are reached within 12 to 24 hours and remain constant for 72 hours. The time to reach steady-state plasma concentrations is approximately 24 to 48 hours and the percentage of the total dose delivered in 7 days was $15 \%$. The buprenorphine patch is to be titrated with oral IR opioids. Following patch removal, concentrations decreased to one-half in 12 hours, then declined more gradually with a terminal half-life of 26 hours $(159,160)$. Precautions should be 
exercised with the use of buprenorphine and avoided in patients with hypokalemia, unstable heart failure, atrial fibrillation, and with other QT prolongation pharmacotherapies. Buprenorphine is a QT prolonging opioid, and is further incompletely reversible by naloxone (161). PG category is $C$.

\section{Nalbuphine}

Nalbuphine hydrochloride is a synthetic partial opioid agonist-antagonist analgesic of the phenanthrene family. It is chemically related to opioid antagonists and also to oxymorphone. Nalbuphine is available as a solution for injection (IV, IM, SC). Nalbuphine hydrochloride is primarily a kappa agonist/mu partial antagonist analgesic, but it also binds to the delta receptors (162-164). Its analgesic potency is essentially equivalent to that of morphine on a milligram basis $(165,166)$. The onset of action occurs within 2 to 3 minutes after IV administration, and in less than $15 \mathrm{~min}$ utes following SC or IM injection. The plasma half-life of nalbuphine is 5 hours utilizing hepatic metabolism, and in clinical studies the duration of analgesic activity has been reported to range from 3 to 6 hours (167169). The opioid antagonist activity of nalbuphine is one-fourth as potent as nalorphine and 10 times that of pentazocine. Nalbuphine hydrochloride may produce the same degree of respiratory depression as equianalgesic doses of morphine. However, it exhibits a ceiling effect such that increases in dosage greater than $30 \mathrm{mg}$ do not produce further respiratory depression in the absence of other CNS active medications affecting respiration (165). Nalbuphine hydrochloride by itself has potent opioid antagonist activity at doses equal to or lower than its analgesic dose. When administered following or concurrent with mu agonist opioid analgesics (e.g., morphine, oxymorphone, fentanyl), nalbuphine hydrochloride may partially reverse or block opioid-induced respiratory depression from the mu receptor agonist analgesic (165). Nalbuphine hydrochloride may precipitate withdrawal in patients dependent on opioid drugs and thus should be used with caution in patients who have been receiving $\mathrm{mu}$ opioid analgesics on a regular basis $(163,170)$. Nalbuphene has been utilized epidurally for opioid-induced pruritis. PG category is $C$.

\section{Conclusions}

A higher degree of clinical science is necessitated for prescribing an NSAID than prescribing an opioid. Opioid prescribing, however, necessitates a more comprehensive clinical vigilance over time addressing outcomes of augmented functionality and activities of daily living provided by opioid pharmacotherapy. Further vigilance is directed to opioid pharmacotherapy adherence, compliance, abuse, misuse, and diversion. Clinical urine drug testing by confirmatory testing is essential in collaboration with a controlled substance agreement.

The opioids as a class have significant differences in pharmacokinetics, pharmacodynamics, pharmacology, mechanisms of activity, and disease specific utility. The prescriber of an opioid agent should possess the required current opioid pharmacotherapy knowledge, judgment, and wisdom to apply a patient-specific, patient-focused, patient-centered personalized management plan for pain which will most appropriately benefit and address the patient's pain etiologies.

\section{References}

1. Schatman ME. Pain medicine: Business or profession? Medscape Neurology 2011. www.medscape.com/viewarticle/742692. Accessed 5/20/2011.

2. Smith HS, Barkin RL. Fibromyalgia syndrome: A discussion of the syndrome and pharmacotherapy. Am J of Therapeutics 2010;17:419-439.

3. Barkin, RL, lusco A, Barkin S. Weiner's Pain Management: A Practical Guide for Clinicians. 7th Ed. CRC Press, New York, 2006, pp 779-794.
4. Barkin RL. Incorporation of science and clinical medicine in the process of patient-specific and patient-centered, patient focused prescribing and personalize patient care. Pain Med Network 2008; 23:4-9.

5. Foley KM. Opioids. Neurol Clin 1993; 11:503-522.

6. Jaffe JH, Martin WR. Goodman and Gilman's The Pharmacological Basis of Therapeutics. 8th ed. Pergamon Press, New York, 1990, pp 485-521.
Di Chiara G, Imperato A. Opposite effects of mu and kappa opiate agonists on dopamine release in the nucleus accumbens and in the dorsal caudate of freely moving rats. J Pharmacol Exp Ther 1988; 244:1067-1080.

8. Leone P, Pocock D, Wise RA. Morphine dopamine interaction: Ventral tegmental morphine increases nucleus accumbens dopamine release. Pharmacol Biochem Beh 1991; 39:469-472.

9. Matthews RT, German DC. Electro- 
physiological evidence for excitation of rat ventral tegmental area dopaminergic neurons by morphine. Neuroscience 1984; 11:617-626.

10. Kieffer BL, Befort K, Gaveriaux-Ruff C, Hirth CG. The delta-opioid receptor: Isolation of a cDNA by expression cloning and pharmacological characterization. Proc Natl Acad Sci USA 1992; 89:12048-12052.

11. Evans CJ, Erdelyi E, Weber E, Barchas JD. Identification of pro-opiomelanocortin-derived peptides in the human adrenal medulla. Science 1992; 258:19521955 .

12. Chen Y, Fan Y, Liu J, Mestek A, Tian M, Kozak CA, Yu L. Molecular cloning, tissue distribution and chromosomal localization of a novel member of the opioid receptor gene family. FEBS Lett 1994; 347:279-283.

13. Mollereau C, Parmetier M, Mailleux P, Butour JL, Moisand C, Chalon P, Caput D, Vassart G, Meunier JC. ORLı, a novel member of the opioid receptor family. Cloning, functional expression, and localization. FEBS Lett 1994; 341:33-38.

14. Anton B, Fein J, To T, Li X, Silberstein L, Evans CJ. Immunohistochemical localization of ORL-1 in the central nervous system of the rat. J Comp Neurol 1996; 368:229-251.

15. Paul D, Bodnar RJ, Gistrak MA, Pasternak GW. Different mu receptor subtypes mediate spinal and supraspinal analgesia in mice. Eur J Pharmacol 1989; 168:307-314.

16. Lacoste A, Evans CJ. The Delta Receptor. Marcel Dekker, New York, 2004, pp 1530.

17. Wollemann M, Benyhe S, Simon J. The kappa-opioid receptor: Evidence for the different subtypes. Life Sciences 1993; 52:599-611.

18. Akil H, Watson SJ, Young E, Lewis ME, Khachaturian $\mathrm{H}$, Walker JM. Endogenous opioids: Biology and function. Ann Rev Neurosci 1984; 7:223-255.

19. Capogna M, Gähwiler BH, Thompson SM. Mechanism of mu-opioid receptormediated presynaptic inhibition in the rat hippocampus in vitro. J Physiol 1993; 470:539-558.

20. Werz MA, MacDonald RL. Opioid peptides decrease calcium-dependent action potential duration of mouse dorsal root ganglion neurons in cell culture. Brain Research 1982; 239:315-321.

21. Vaughan CW, Christie MJ. Presynaptic inhibitory action of opioids on synaptic transmission in the rat periaqueductal grey in vitro. J Physiol 1997; 498:463-467.

22. Bradford HF, Crowder JM, White EJ. Inhibitory actions of opioid compounds on calcium fluxes and neurotransmitter release from mammalian cerebral cortical slices. Br J Pharmacol 1986; 88:87-93.

23. Inturrisi CE, Lipman AG. Bonica's Management of Pain. 4th Ed. Lippincott, Williams \& Wilkins, Philadelphia, 2009, pp 1172-1186.

24. Jhamandas $\mathrm{KH}$. Opioid-neurotransmitter interactions: Significance in analgesia, tolerance and dependence. Prog Neuro-Psychopharmacol Biol Psychiatr 1984; 8:565-570.

25. Pepper CM, Henderson G. Opiates and opioid peptides hyperpolarize locus coeruleus neurons in vitro. Science 1980; 209:394-395.

26. Werz MA, MacDonald RL. Opioid peptides selective for mu- and delta-opiate receptors reduce calcium-dependent action potential duration by increasing potassium conductance. Neurosci Lett 1983; 42:173-178.

27. Pan ZZ. א-Opioid receptor-mediated enhancement of the hyperpolarization-activated current (Ih) through mobilization of intracellular calcium in rat nucleus raphe magnus. J Physiol 2003; 583:765-775.

28. Ossipov MH, Dussor GO, Porreca F. Central modulation of pain. J Clin Invest 2010; 120:3779-3787.

29. Thompson JW. Opioid peptides. Br Med J 1984; 288:259-261.

30. Schlaepfer TE, Strain EC, Greenberg $\mathrm{BD}$, Preston KL, Lancaster E, Bigelow GE, Barta PE, Pearlson GD. Site of opioid action in the human brain: $M u$ and kappa agonists' subjective and cerebral blood flow effects. Am J Psychiatr 1998; 155:470-473.

31. Simon EJ, Hiller JM. The opiate receptors. Ann Rev Pharmacol Toxicol 1978; 18:371-394.

32. McDonald J, Lambert DC. Opioid receptors. CEACCP 2005; 5:22-25.

33. Coda BA. Clinical Anesthesia. 6th Ed. Lippincott Williams \& Wilkins, Philadelphia, 2009, pp 464-497.

34. Trivedi M, Shaikh S, Gwinnut C. Pharmacology of opioids. Update in Anaesthesia 2011, pp 118-124. www.worldanesthesia.org.

35. Gordon DB, Stevenson KK, Griffie J, Muchka S, Rapp C, Ford-Roberts K.
Opioid equianalgesic calculations. J Pall Med 2005; 2:209-218.

36. Gammaitoni $A R$, Fine $P$, Alvarez $N$, McPherson ML, Bergmark S. Clinical application of opioid equianalgesic data. Clin J Pain 2003; 19:286-297.

37. Kupers RC, Konings $\mathrm{H}$, Adriaensen $\mathrm{H}$, Gybels JM. Morphine differentially affects sensory and affective pain ratings in neurogenic and diopathic forms of pain. Pain 1991; 47:5-12.

38. Aner S, Meyerson BA. Lack of analgesic effect of opioids on neuropathic and idiopathic forms of pain. Pain 1988; 33:1123.

39. Trescot AM, Datta S, Lee M, Hansen H. Opioid pharmacology. Pain Physician 2008; 11:S133-153.

40. Kilpatrick GJ, Smith TW. Morphine6-glucuronide: Actions and mechanisms. Med Res Rev 2005; 25:521-544.

41. van Dorp EL, Romberg R, Sarton E, Bovill JG, Dahan A. Morphine-6-glucuronide: Morphine's successor for postoperative pain relief? Anesth Analg 2006; 102:1789-1797.

42. Jenkins AJ. Pharmacokinetics of specific drugs. In Karch SB (ed). Pharmacokinetics and Pharmacodynamics of Abused Drugs. CRC Press, Boca Raton, 2008, pp 25-64.

43. Kerr B, Hill H, Coda B, Calogero M, Chapman CR, Hunt E, Buffington V, Mackie A. Concentration-related effects of morphine on cognition and motor control in human subjects. Neuropsychopharmacology 1991; 5:157-166.

44. Friswell J, Phillips C, Holding J, Morgan CJ, Brandner B, Curran HV. Acute effects of opioids on memory functions of healthy men and women. Psychopharmacology 2008; 198:243-250.

45. Galski T, Williams JB, Ehle HT. Effects of opioids on driving ability. J Pain Symptom Manage 2000; 19:200-208.

46. Janicki PK. Pharmacology of morphine metabolites. Curr Pain Headache Rep 1997; 1:264-270.

47. Lötsch J, Stockman A, Kobal G, Brune K, Waibel R, Schmidt N, Geisslinger G. Pharmacokinetics of morphine and its glucuronides after intravenous infusion of morphine and morphine-6-glucuronide in healthy volunteers. Clin Pharmacol Therapeut 1996; 60:316-325.

48. Vater M, Smith G, Aherne GW, Aitkenhead AR. Pharmacokinetics and analgesic effect of slow-release oral morphine sulphate in volunteers. $\mathrm{Br}$ J Anaesth 
1984; 56:821-827.

49. Gharibo C. Managing chronic moderate to severe pain-Embeda ${ }^{\circledR}$ (Morphine sulfate and naltrexone hydrochloride) extended release capsules for oral use. US Neurol 2010; 6:18-22.

50. Carlozzi AF, Fornari FA, Siwicki DM, Barkin RL, Nafziger AN, Woodcock M, Johnson C, Rodriguez AJ, Bertino JS, Bauer GB, Michner E, Aronoff G, Empting LD. Urine Drug Monitoring: Opioids. McMahon Publishing Group, 2009.

51. Quigley C: Hydromorphone for acute and chronic pain. Cochrane Database Syst Rev 2002; 1:CDoo3447

52. Sathyan G, Xu E, Thipphawong J, Gupta SK. Pharmacokinetic profile of a 24 -hour controlled-release $\mathrm{OROS}^{\circledR}$ formulation of hydromorphone in the presence and absence of food. BMC Clin Pharmacol 2007; 7:2-9.

53. Inturrisi CE: Clinical pharmacology of opioids for pain. Clin J Pain 2002; 8:S313.

54. Sarhill N, Walsh D, Nelson KA. Hydromorphone: Pharmacology and clinical applications in cancer patients. Support Care Cancer 2001; 9:84-96.

55. Kumar P, Sunkaraneni S, Sirohi S, Dighe SV, Walker EA, Yoburn BC. Hydromorphone efficacy and treatment protocol impact on tolerance and mu-opioid receptor regulation. Eur J Pharmacol 2008; 597:39-45.

56. Vallner JJ, Stewart JT, Kotzan JA, Kirsten EB, Honigberg IL. Pharmacokinetics and bioavailability of hydromorphone following intravenous and oral administration to human subjects. J Clin Pharmacol 1981; 21:152-156.

57. Hennies HH, Friderichs E, Schneider J. Receptor binding, analgesic and antitussive potency of tramadol and other selected opioids. Arzneimittelforschung 1988; 38:877-880.

58. Wright AW, Mather LE, Smith MT. Hydromophone-3-glucuronide: A more potent neuro-excitant than its structural analogue, morphine-3-glucuronide. Life Sci 2001;69: 409-420.

59. Guay DR. Use of oral oxymorphone in the elderly. Consult Pharm 2007; 22:417430.

6o. Thwaites D, McCann S, Broderick P. Hydromophone neuroexcitation. J Palliat Med 2004 ;7:545-550.

61. Warolin C. Pierre-Jean Robiquet. Rev Hist Pharm (Paris) 1999; 47:97-110. [French]
62. Smith HS. Opioid metabolism. Mayo Clin Proc 2009; 84:613-624.

63. Thorn CF, Klein TE, Altman RB. Codeine and morphine pathway. Pharmacogenet Genomics 2009; 19:556-558.

64. Rossi S, (ed). Australian Medicines Handbook. Australian Medicines Handbook, Adelaide, 2004.

65. Vree TB, van Dongen RT, KoopmanKimenai PM. Codeine analgesia is due to codeine-6-glucuronide, not morphine. Int J Clin Pract 2000; 54:395-398.

66. Srinivasan V, Wielbo D, Tebbett IR. Analgesic effects of codeine-6-glucuronide after intravenous administration. Eur J Pain 1997; 1:185-190.

67. Reynolds L, Rauck R, Webster L, DuPen $S$, Heinze $E$, Portenoy $R$, Katz $N$, Charapata S, Wallace M, Fisher DM. Relative analgesic potency of fentanyl and sufentanil during intermediate-term infusions in patients after long-term opioid treatment for chronic pain. Pain 2004; 10:182-188.

68. Lichtor JL, Sevarino FB, Joshi GP, Busch MA, Nordbrock E, Ginsberg B. The relative potency of oral transmucosal fentanyl citrate compared with intravenous morphine in the treatment of moderate to severe postoperative pain. Anesth Analg 1999; 89:732-738.

69. Kim KS, Simon L. Transport mechanisms in oral transmucosal drug delivery: Implications for pain management. Math Biosci 2011; 229:93-100.

70. Vasisht N, Gever LN, Tagarro I, Finn AL. Evaluation of the single- and multipledose pharmacokinetics of fentanyl buccal soluble film in normal healthy volunteers. J Clin Pharmacol 2010; 50:785-791.

71. Grape S, Schug SA, Lauer S, Schug BS. Formulations of fentanyl in the management of pain. Drugs 2010; 70:57-72.

72. Nelson L, Schwaner R. Transdermal fentanyl: Pharmacology and toxicology. J Med Toxicol 2009; 5:230-241.

73. Jeal W, Benfield P. Transdermal fentanyl. A review of its pharmacological properties and therapeutic efficacy in pain control. Drugs 1997; 53:109-138.

74. Dean M. Opioids in renal failure and dialysis patients. J Pain Symptom Manage 2004; 28:497-504.

75. Tegeder I, Lötsch J, Geisslinger G. Pharmacokinetics of opioids in liver disease. Clin Pharmacokinet 1999; 37:17-40.

76. Prommer E. Levorphanol: The forgotten opioid. Support Care Cancer 2007; 15:259-
264.

77. Zhang A, Xiong W, Bidlack JM, Hilbert JE, Knapp BI. Wentland MP, Neumeyer JL. 10-Ketormorphinan and 3-substituted-3-desoxymorphian analogues as mixed kappa and micro opioid ligands: Synthesis and biological evaluation of their binding aflinity at opioid receptors. J Med Chem 2004; 47:165-174.

78. Wang Y, Li JG. Huang P, Xu W, Liu-Chen LY. Differential effects of agonists on adenylyl cyclase superactivation mediated by the kappa opioid receptors: Adenylyl cyclase superactivatian is independent of agonist-induced phosphorylation, desensitization, internalization, and down-regulation. J Pharmacol Exp Ther 2003; 307:1127-1134.

79. Tive L, Ginsberg K, Pick CG, Pasternak GW. Kappa 3 receptors and levorphanolinduced analgesia. Neuropharmacology 1992; 31:851-856.

8o. Moulin DE, Ling GS, Pasternak GW. Unidirectional analgesic cross-tolerance between morphine and levorphanol in the rat. Pain 1988 ;33:233-239.

81. Blake AD, Bat G, Li S, Freeman JC, Reisine $T$. Differential agonist regulation of the human kappa-opioid receptor. J Neurochem 1997; 68:1846-1852.

82. Stringer M, Makin MK, Miles J, Morley JS. D-morphine, but not L-morphine, has low micromolar affinity for the noncompetitive $\mathrm{N}$-methyl-D-aspartate site in rat forebrain. Possible clinical implications for the management of neuropathic pain. Neurosci Lett 2000; 295:2124 .

83. McNulty JP. Can levorphanol be used like methadone for intractable refractory pain? J Palliat Med 2007; 10:293-296.

84. Labella FS, Pinsky C, Havlicek V. Morphine derivatives with diminished opiate receptor potency show enhanced central excitatory activity. Brain Res 1979; 174:263-271.

85. Lomenzo SA, Rhoden JB, Izenwasser S, Wade D, Kopajtic T, Katz JL, Trudell ML. Synthesis and biological evaluation of meperidine analogues at monoamine transporters. J Med Chem 2005; 48:13361343.

86. Marinella MA. Meperidine-induced generalized seizures with normal renal function. South Med J 1997; 90:556-558.

87. Armstrong SC, Wynn GH, Sandson NB. Pharmacokinetic drug interactions of synthetic opiate analgesics. Psychosomatics 2009; 50:169-176. 
88. Sporer KA. The serotonin syndrome. Implicated drugs, pathophysiology and management. Drug Saf 1996; 15:8-29.

89. Gillman PK. Monoamine oxidase inhibitors, opioid analgesics and serotonin toxicity. Br J Anaesth 2005; 95:434-441.

90. Seifert CF, Kennedy S. Meperidine is alive and well in the new millennium: Evaluation of meperidine usage patterns and frequency of adverse drug reactions. Pharmacotherapy 2004; 24:776783.

91. Wainer BH, Wung WE, Hill JH, Fitch FW, Fried J, Rothberg RM. The production and characterization of antibodies reactive with meperidine. J Pharmacol Exp Ther 1976; 197:734-743.

92. Latta KS, Ginsberg B, Barkin RL. Meperidine: A critical review. Am J of Ther 2002; 9:53-58.

93. Szeto $\mathrm{HH}$, Lovelace JL, Fridland G, Soong Y, Fasolo J, Wu D, Desiderio DM, Schiller PW. In vivo pharmacokinetics of selective mu-opioid peptide agonists. J Pharmacol Exp Ther 2001; 298:57-61.

94. Ikeda T, Kurz A, Sessler DI, Go J, Kurz $M$, Belani K, Larson M, Bjorksten AR, Dechert M, Christensen R. The effect of opioids on thermoregulatory responses and the special antishivering action of meperidine. Ann N Y Acad Sci 1997; 813:792-798.

95. Stambaugh JE, Wainer IW, Sanstead JK, Hemphill DM. The clinical pharmacology of meperidine-comparison of routes of administration. J Clin Pharmacol 1976; 16:245-256.

96. Stringer J, Welsh C, Tommasello A. Methadone-associated Q-T interval prolongation and torsades de pointes. Am J Health Syst Pharm 2009; 66:825-833.

97. Perrin-Terrin A, PathakA, Lapeyre-Mestre M. QT interval prolongation:Prevalence, risk factors and pharmacovigilance data among methadone-treated patients in France. Fundam Clin Pharmacol 2011; 25:503-510.

98. Heppe DB, Haigney MC, Kranz MJ. The effect of oral methadone on the QTC interval in advanced cancer patients: A prospective pilot study. J Palliat Med 2010; 13:638-639.

99. Huh B, Park $\mathrm{CH}$. Retrospective analysis of low-dose methadone and QTc prolongation in chronic pain patients. Korean J Anesthesiol 2010; 58:338-343.

100. Burgess FW, Krantz MJ, Barkin RL. Methadone: Unintended mortality due to overdose and arrhythmia. Pain Med (Special Edition) 2007; 5:25-31.
101. Fredheim OM, Moksnes K, Borchgrevink PC, Daasa S, Dale O. Clinical pharmacology of methadone for pain. Acta Anaesthesiol Scand 2008; 52:879889.

102. Fredheim OM, Borchgrevink PC, Klepstad P, Kaasa S, Dale O. Long term methadone for chronic pain: A pilot study of pharmacokinetic aspects. Eur J Pain 2007; 11:599-604.

103 Chou R, Fanciullo GJ, Fine PG, Adler JA, Ballantyne JC, Davies P, Donovan MI, Fishbain DA, Foley KM, Fudin J, Gilson AM, Kelter A, Mauskop A, O'Connor PG, Passik SD, Pasternak GW, Portenoy RK, Rich BA, Roberts RG, Todd KH, Miaskowski C; American Pain Society-American Academy of Pain Medicine Opioids Guidelines Panel. Clinical guidelines for the use of chronic opioid therapy in chronic noncancer pain. J Pain 2009; 10:113-130.

104. Xiao Y, Smith RD, Caruso FS, Kellar KJ. Blockade of rat alphazbeta4 nicotinic receptor function by methadone, its metabolites, and structural analogs. J Pharmacol Exp Ther 2001; 299:366-371.

105. Pergolizzi J, Böger RH, Budd K, Dahan A, Erdine S, Hans G, Kress HG, Langford R, Likar R, Raffa RB, Sacerdote P. Opioids and the management of chronic severe pain in the elderly: Consensus statement of an international expert panel with focus on the six clinically most often used World Health Organization Step III opioids (buprenorphine, fentanyl, hydromorphone, methadone, morphine, oxycodone). Pain Pract 2008; 8:287-313.

106. Weschules DJ, Bain KT. A systematic review of opioid conversion ratios used with methadone for the treatment of pain. Pain Med 2008; 9:595-612.

107. Denson DD, Concilus RR, Gregg RV, Crews JC. The correlation between predicted and measured patient specific analgesic concentrations after intravenous titration: A guide for initial maintenance requirements with methadone. J Clin Pharmacol 1990; 30:1049-1054.

108. Fingerhut LA. Increases in poisoning and methadone-related deaths: United States, 1999-2005. NCHS Heath \& Stats February 2008. http://cdc.gove/nchs/ data/hestat/poisoning/poisoning.pdf. Accessed 02/14/2011.

109. Gouldin WM, Kennedy DT, Small RE. Methadone: History and recommendations for use in analgesia. APS Bulletin 2000; 10:1-11www.ampainsoc.org/pub/ bulletin/sepoo/updar.htm. Accessed
O1/29/2011.

110. Cone E, Darwin W, Gorodetzky C, Tan T. Comparative metabolism of hydrocodone in man, rat, guinea pig, rabbit, and dog. Drug Metab Dispos 1978; 6:488-493.

111. Chen ZR, Irvine RJ, Somogyi AA, Bochner $\mathrm{F}$. Mu receptor binding of some commonly used opioids and their metabolites. Life Sci 1991; 48:2165-2171.

112. Kaplan HL, Busto UE, Baylon GJ, Cheung SW, Otton SV, Somer G, Cheung SW, Otton SV, Somer G, Sellers EM. Inhibition of cytochrome $\mathrm{P}_{450}$ 2D6 metabolism of hydrocodone to hydromorphone does not importantly affect abuse liability. J Pharmacol Exp Ther 1997; 281:103-108.

113. Hutchinson MR, Menelaou A, Foster DJR, Coller JK, Somogyi AA. CYP2D6 and $\mathrm{CYP}_{3} \mathrm{~A}_{4}$ involvement in the primary oxidative metabolism of hydrocodone by human liver microsomes. $\mathrm{Br}] \mathrm{Clin}$ Pharmacol 2003; 57:287-297.

114. Daly A, Brockmoller J, Broly F, Eichelbaum M, Evans WE, Gonzalez FJ, Huang JD, Idle JR, Ingelman-Sundberg $M$, Ishizaki T, Jacqz-Aigrain E, Meyer UA, Nebert DW, Steen VM, Wolf CR, Zanger UM. Nomenclature for human CYP2D6 alleles. Pharmacogenetics 1996; 6:193201.

115. Kroemer HK, Eichelbaum M. "It's the genes, stupid." Molecular bases and clinical consequences of genetic cytochrome $\mathrm{P}_{450}$ 2D6 polymorphism. Life Sci 1995; 56:2285-2298.

116. Lalovic B, Kharasch E, Hoffer C, Risler L, Liu-Chen LY, Shen DD. Pharmacokinetics and pharmacodynamics of oral oxycodone in healthy human subjects: Role of circulating active metabolites. Clin Pharmacol Ther 2006; 79:461-479.

117. Kailko RF, Benziger DP, Fitzmartin RD, Burke BE, Reder RF, Goldenheim PD. Pharmacokinetic-pharmadynamic relationships of controlled-release oxycodone. Clin Pharmacol Ther 1996; 59:52-61.

118. Pöyhiä R, Vainio A, Kalso E. A review of oxycodone's clinical pharmacokinetics and pharmacodynamics. J Pain Symptom Manage 1993; 8:63-67.

119. Davis MP, Varga J, Dickerson D, Walsh D, LeGrand SB, Lagman R. Normal-release and controlled-release oxycodone: Pharmacokinetics, pharmacodynamics and controversy. Support Care Cancer 2003; 11:84-92.

120. Duttaroy A, Yoburn BC. The effect of intrinsic efficacy on opioid tolerance. Anesthesiology 1995; 82:1226-1236. 
121. Nielsen CK, Ross FB, Lotfipour S, Saini KS, Edwards SR, Smith MT. Oxycodone and morphine have distinctly different pharmacological profiles: Radioligand binding and behavioural studies in two rat models of neuropathic pain. Pain 2007; 132:289-300.

122. Ross FB, Smith MT. The intrinsic antinociceptive effects of oxycodone appear to be kappa-opioid receptor mediated. Pain 1997; 73:151-157.

123. Olesen AE, Upton R, Foster DJ, Staahl C, Christrup LL, Arendt-Nielsen L, Drewes AM. A pharmacokinetic and pharmacodynamic study of oral oxycodone in a human experimental pain model of hyperalgesia. Clin Pharmacokinet 2010; 49:817-827.

124. Kok GB, Pye CC, Singer RD, Scammells PJ. Two-sept iron(o)-mediated N-demethylation of $\mathrm{N}$-methyl alkaloids. J Org Chem 2010; 75:4806-4811.

125. Sloan P. Review of oral oxymorphone in the management of pain. Therapeut Clin Risk Manage 2008; 4:777-787.

126. Sinatra RS, Lodge K, Sibert K, Chung KS, Chung JH, Parker A Jr, Harrison DM. A comparison of morphine, meperidine, and oxymorphone as utilized in patientcontrolled analgesia following cesarean delivery. Anesthesiology 1989; 70:585-590.

127. Sloan PA, Slatkin NE, Ahdieh H. Effectiveness and safety of oral extended-release oxymorphone for the treatment of cancer pain: A pilot study. Supp Care Cancer 2005; 13:57-65.

128. Adams MP, Ahdieh H. Single- and multiple-dose pharmacokinetic and doseproportionality study of oxymorphone immediate-release tablets. Drugs $R D$ 2005; 6:91-99.

129. Gimbel J, Ahdieh H. The efficacy and safety of oral immediate-release oxymorphone for postsurgical pain. Anesth Analg 2004; 99:1472-1477.

130. Guay DR. Oral oxymorphone extendedrelease. Consult Pharm 2010; 25:816-828.

131. Matsumoto AK. Oral extended-release oxymorphone: A new choice for chronic pain relief. Expert Opin Pharmacother 2007; 8:1515-1527.

132. Adams M, Pieniaszek HJ Jr, Gammaitoni $A R$, Ahdieh H. Oxymorphone extended release does not affect $\mathrm{CYP}_{2} \mathrm{C}_{9}$ or $\mathrm{CY}$ $\mathrm{P}_{3} \mathrm{~A}_{4}$ metabolic pathways.] Clin Pharmacol 2005; 45:337-345.

133. Sloan PA, Barkin RL. Oxymorphone and oxymorphone extended release: A pharmacotherapeutic review. J Opioid Manage 2008; 4:3131-144.
134. Uysal HY, Takmaz SA, Yaman F, Baltaci $B$, Baar $H$. The efficacy of intravenous paracetamol versus tramadol for postoperative analgesia after adenotonsillectomy in children. J Clin Anesth 2011; 23:53-57.

135. Sansone RA, Sansone LA. Tramadol: Seizures, serotonin syndrome, and coadministered antidepressants. Psychiatry (Edgmont) 2009; 6:17-21.

136. Grond S, Sablotzki A. Clinical pharmacology of tramadol. Clin Pharmacokinetics 2004; 3:879-923.

137. Katz W, Barkin RL. Dilemmas in chronic/ persistent pain management. Am J Ther 2008; 15:256-264.

138. Barkin RL. Extended-release tramadol (ULTRAM®ER): A pharmacotherapeutic, pharmacokinetic, and pharmacodynamic focus on effectiveness and safety in patients with chronic/persistent pain. Am J Ther 2008; 15:157-166.

139. Wade WE, Spruill WJ. Tapentadol hydrochloride: A centrally acting oral analgesic. Clin Ther 2009; 31:2804-2818.

140. Barkin RL. Tapentadol: A pharmacotherapeutic focused brief review. Pain Med Network 2009; 24:8,11.

141. Tzschentke TM, De Vry J, Terlinden R, Hennies $\mathrm{H}$, Lange $\mathrm{C}$, Strassburger $\mathrm{W}$, Haurand M, Kolb J, Schneider J, Buschmann $H$, Finkam $M$, Jahnel $U$, Friderichs $\mathrm{E}$. Tapentadol hydrochloride: Analgesic mu-opioid receptor agonist noradrenaline reuptake inhibitor. Drugs Future 2006; 31:1053-1061.

142. West JC, Kosten TR, Wilk J, Svikis D, Triffleman E, Rae DS, Narrow WE, Duffy FF, Regier DA. Challenges in increasing access to buprenorphine treatment for opiate addiction. Am J Addict 2004; 13:S9-S16.

143. Connock M, Juarez-Garcia A, Jowett $S$, Frew E, Liu Z, Taylor RJ, Fry-Smith A, Day E, Lintzeris N, Roberts T, Buris A, Taylor RS. Methadone and buprenorphine for the management of opioid dependence: A systematic review and economic evaluation. Heath Technol Assess 2007; 11:1-171.

144. Soyka M, Apelt SM, Lieb M, Wittchen $\mathrm{HU}$. One-year mortality rates of patients receiving methadone and buprenorphine maintenance therapy: A nationally representative cohort study in 2694 patients. J Clin Psychopharmacol 2006; 26:657-66o.

145. Martin WR, Eades CG, Thompson JA, Huppler RE, Gilbert PE. The effects of morphine- and nalorphine-like drugs in the nondependent and morphine-dependent chronic spinal dog. J Pharmacol Exp Ther 1976; 197:517-532.

146. Lutfy K, Cowan A. Buprenorphine: A unique drug with complex pharmacology. Curr Neuropharmacol 2004; 2:395402.

147. Jasinski DR, Haertzen CA, Henningfield JE, Johnson RE, Makhzoumi HM, Miyasato K. Progress Report of the NIDA Addiction Research Center. NIDA Research Monograph, Rockville, 1982; pp 45-52.

148. Bullingham RE, McQuay HJ, Moore RA. Clinical pharmacokinetics of narcotic agonist-antagonist drugs. Clin Pharmacokinet 1983; 8:332-343.

149. Johnson RE, Fudal PJ, Payne R. Buprenorphine: Considerations for pain management. J Pain Symptom Manage 2005; 29:297-326.

150. Bullingham RE, McQuay HJ, Moore A, Bennett MR. Buprenorphine kinetics. Clin Pharmacol Ther 1980; 28:667-672.

151. Watson PJQ, McQuay HJ, Bullingham RE, Allen MC, Moore RA. Single-dose comparison of buprenorphine 0.3 and $0.6 \mathrm{mg}$ i.v. given after operation: Clinical effects and plasma concentration. $\mathrm{Br}$ J Anaesth 1982; 54:37-43.

152. Walter DS, Inturrisi CE. Absorption, distribution, metabolism, and excretion of buprenorphine in animals and humans. In: Cowan A, Lewis JW (eds). Buprenorphine: Combatting Drug Abuse with a Unique Opioid. Wiley-Liss, New York, 1995, pp 113-135.

153. Iribarne C, Picart D, Dreano Y, Bail JP, Berthou F. Involvement of cytochrome $\mathrm{P}_{45} \mathrm{O}_{3} \mathrm{~A}_{4}$ in $\mathrm{n}$-dealkylation of buprenorphine in human liver microsomes. Life Sci 1997; 60:1953-1964.

154. Kobayashi K, Yamamoto T, Chiba K, Tani M, Shimada N, Ishizaki T, Kuroiwa Y. Human buprenorphine $\mathrm{N}$-dealkylation is catalyzed by cytochrome $\mathrm{P}_{450}{ }_{3} \mathrm{~A}_{4}$. Drug Metab Dispos 1998; 26:818-821.

155. Mendelson J, Upton RA, Everhart ET, Jacob P 3 rd, Jones RT. Bioavailability of sublingual buprenorphine. J Clin Pharmacol 1997; 37:31-37.

156. Everhart ET, Cheung P, Shwonek P, Zabel K, Tisdale EC, Jacob P, Mendelson J, Jones RT. Subnanogram-concentration measurement of buprenorphine in human plasma by electron-capture capillary gas chromatography: Application to pharmacokinetics of sublingual buprenorphine. Clin Chem 1997; 43:22922302. 
157. Bullingham RE, McQuay HJ, Dwyer D, Allen MC, Moore RA. Sublingual buprenorphine used postoperatively: Clinical observations and preliminary pharmacokinetic analysis. Br J Clin Pharmacol 1981; 12:117-122.

158. Bullingham RE, McQuay HJ, Porter EJ, Allen MC, Moore RA. Sublingual buprenorphine used postoperatively: Tenhour plasma drug concentration analysis. Br J Clin Pharmacol 1982; 13:665-673.

159. Reidenberg B, El-Tahtawy A, Munera C, Cipriano A, Tonelli A, Reder R. Absolute bioavailability of a novel buprenorphine transdermal system (BTDS) applied for 7 days. J Clin Pharmacol 2001; 41:1026.

160. Reidenberg B, El-Tahtawy A, Munera C, Cipriano A, Tonelli A, Reder R. Daily pharmacokinetic performance of a buprenorphine transdermal system (BTDS) for up to 7 days. J Clin Pharmacol 2001; 41:1027.

161. Malinoff HL, Barkin RL, Wilson G. Sublingual buprenorphine is effective in the treatment of chronic pain syndrome. Am J Ther 2005; 12:379-384.

162. Chen JC, Smith ER, Cahill M, Cohen R, Fishman JB. The opioid receptor binding of dezocine, morphine, fentanyl, butorphanol, and nalbuphine. Life Sci 1993; 52:389-396.

163. Schmidt WK, Tam SW, Shotzberger GS, Smith Jr DW, Clark R, Vernier VG. Nalbuphine. Drug Alcohol Dep 1985; 14:339362.

164. DeSouza EB, Schmidt WK, Kuhar MJ. Nalbuphine: An autoradiographic opioid receptor binding profile in the central nervous system of an agonist/antagonist analgesic. J Pharmacol Exp Ther 1988; 244:391-402.

165. Gunion MW, Marchionne AM, Anderson CTM. Use of the mixed agonist-antagonist nalbuphine in opioid based analgesia. Acute Pain 2004; 6:29-39.

166. Beaver WT, Feise GA. A comparison of the analgesic effect of intramuscular na-
Ibuphine and morphine in patients with postoperative pain. ] Pharmacol Exp Ther 1978; 204:487-496.

167. Errick JK, Heel RC. Nalbuphine. A preliminary review of its pharmacological properties and therapeutic efficacy. Drugs 1983; 26:191-211.

168. Lo MW, Lee FH, Schary WL, Whitney CC. The pharmacokinetics of intravenous, intramuscular, and subcutaneous nalbuphine in healthy subjects. Eur ] Clin Pharmacol 1987; 33:297-301.

169. Jaillon $P$, Gardin ME, Lecocq B, Richard MO, Meignan S, Blondel Y, Grippat JC, Bergnieres J, Vergnoux O. Pharmacokinetics of nalbuphine in infants, young healthy volunteers, and elderly patients. Clin Pharmacol Ther 1989; 46:226-233.

170. Gutstein HB, Akil H. Opioid analgesics. In: Hardman JG, Limbird LE (eds). Goodman \& Gilman's The Pharmacological Basis of Therapeutics. 1oth ed. McGrawHill, New York, 2001, pp 569-619. 